\title{
Restocking Untuk Pelestarian Ikan Nila (Oreochromis Niloticus) Di Danau Kemuning Bandar Sribhawono Lampung Timur
}

\author{
M. Hadziq Qulubi \\ Universitas Nahdlatul Ulama Lampung \\ Email: qulubih@gmail.com
}

\begin{abstract}
:
Some factors that may lead to the decline in fish populations are due to habitat change, excess exploitation, due to foreign fish introduction and the consequences of global warming, as well as due to competition in water use and pollution. Fish is very important as a provider of animal proteins for the fulfillment of community nutrition especially for children in the period of growth. The supply of fish in East Lampung still relies on the catch, because it needs to be maintained the availability of fish stocks in common water. One attempt to retain fish stocks in common waters is to carry out restocking or fish redistribution activities in their habitat. This activity was held on the day of June 12, 2016 by lecturers and BEM UNU Lampung in cooperation with the village and district government of Bandar Sribhawono. The type of fish that is stocked is oreochromis niloticus amounting to 11,000 tails. Oreochromis niloticus chosen because the fish has high adaptability and fast breeding. Restocking activities have a good welcome and positive response from local communities. The effort to maintain and improve the function of Lake Kemuning is increasingly evident with the increasing number of floating nets and tour development plans in the lake area.
\end{abstract}

Keyword: restocking, Oreochromis Niloticus, lake Kemuning

\section{Pendahuluan}

Peranan perairan umum (danau) dalam kehidupan manusia sangatlah penting yaitu sebagai sumber air tawar, sumber keanekaragaman hayati, sumber ketahanan pangan dan sumber perekonomian sehingga bisa dikatakan perairan umum bersifat multifungsi, multiguna dan multipemanfaatan berbagai sektor pembangunan. Luas perairan umum atau perairan tawar (freshwater) Indonesia sekitar 5,4 juta hektar (ha), yang meliputi danau, sungai, rawa, waduk/bendungan, 


\section{0 | Restocking untuk Pelestarian Ikan Nila}

sawah dan genangan air lainnya (Kordi, 2015). Manusia sebagai pemanfaat telah menggunakan perairan umum untuk berbagai kepentingan, misalnya untuk pembangkit tenaga listrik, irigasi pertanian, perikanan, pariwisata serta pasokan air untuk rumah tangga dan industri bahkan masih digunakan sebagai penampung buangan limbah. Dengan bertambanhnya jumlah penduduk, maka semua aktivitas manusia itu tentu dapat memberikan berbagai dampak negatif terhadap ekosistem perairan seperti kerusakan dan hilangnya habitat ikan, atau punahnya keanekaragaman hayati perairan termasuk sumber daya ikan (Saputra, 1987).

Beberapa faktor yang dapat menyebabkan turunnya populasi ikan antara lain akibat perubahan habitat, eksploitasi berlebih, akibat introduksi ikan asing dan akibat pemanasan global, persaingan penggunaan air, pencemaran dan tingginya laju penangkapan (kordi,2015). Lebih lanjut dikemukakan oleh kordi, stok biota di suatu perairan cenderung semakin berkurang karena tingginya laju penangkapan dan kematian dibanding dengan perkembangbiakan dan pertumbuhan. Laju penangkapan semakin meningkat disebabkan oleh tuntutan pemenuhan kebutuhan manusia yang meningkat sejalan pertumbuhan jumlah penduduk. Laju kematian biota di alam juga meningkat sejalan dengan semakin memburuknya kualitas lingkungan, termasuk rusaknya habitat hidup biota di alam akibat penangkapan yang destruktif, seperti penggunaan bahan peledak, racun, strum listrik, limbah industri dan limbah rumah tangga. Sementara itu, menurut Effendi (2004), laju reproduksi dan pertumbuhan yang tidak secepat laju penangkapan dan kematian biota di alam disebabkan pula oleh memburuknya kualitas lingkungan, termasuk rusaknya habitat hidup biota di alam akibat praktik-praktik penangkapan yang meruasak tersebut.

Hasil perikanan berupa ikan yang sehat sangat penting sebagai penyedia protein hewani bagi pemenuhan gizi masyarakat terutama bagi anak-anak dalam masa pertumbuhan.

Pasokan ikan di Lampung Timur masih mengandalkan hasil tangkapan, karena itu perlu dipertahankan ketersediaan stok ikan di perairan umum. Salah satu 
upaya untuk mempertahankan stok ikan di perairan umum adalah dengan melakukan restocking atau kegiatan penebaran kembali ikan di habitatnya. Menurut Kepala Kantor Penanaman Modal (KPM) Kabupaten Lampung Timur, Potensi perikanan di Kabupaten Lampung Timur cukup besar, sebab dari total lahan perikanan seluas 22.548,05 Ha baru dimanfaatkan 15.909,29 Ha. Pemanfaatan tersebut meliputi perairan payau dan tawar. Adapun jenis ikan air tawar yang banyak dibudidayakan di kabupaten lampung timur adalah ikan lele, ikan nila, ikan gurame dan ikan patin (DKP Lampung Timur, 2017). Dari beberapa jenis ikan tersebut, ikan lele merupakan ikan yang paling banyak dibudidayakan disusul ikan nila.

Sejalan dengan misi Kementerian Kelautan dan Perikanan, restocking ikan diyakini mendukung upaya dalam meningkatkan kesejahteraan masyarakat setempat. Kegiatan restocking ini sering dilakukan di danau dan sungai. Saat ini sudah sering dilakukan kegiatan restocking ikan oleh kelompok-kelompok yang peduli lingkungan, akademisi termasuk di dalamnya Universitas Nahdlatul Ulama Lampung, pemerintah daerah bahkan personal dalam rangka memperingati kegiatan tertentu. Sesuai dengan definisinya, restocking adalah menebarkan kembali jenis-jenis ikan yang menurut sejarahnya mendiami perairan itu yang karena suatu sebab terjadi penurunan populasi atau tidak ditemukan lagi. Menurut Kordi (2015), restoking (restocking) adalah penebaran kembali biota ke suatu perairan untuk peningkatan stok (stock enhancement) maupun pelestarian biota tersebut. Dipilihnya danau sebagai wadah atau tempat untuk melakukan restoking karena danau (lake) adalah genangan air yang luas dengan ketinggian dan luasan permukaan air berfluktuasi kecil yang kedalamanya bisa dangkal atau sangat dalam mempunyai atau tidak mempunyai sungai yang mengalir ke dalam atau ke luar perairan, terbentuk secara alami dan terisolir dari laut (Burhanuddin, 2018).

Kegiatan restocking bertujuan : pertama, menjaga ketersediaan ikan nila, kedua menghidupkan fungsi danau kemuning yang ada di Kecamatan Bandar Sribhawaono Kabupaten Lampung Timur sebagai tempat mencari nafkah bagi 
masyarakat yang berprosesi sebagai nelayan. Ketiga, menjaga keseimbangan alam dimana danau kemuning merupakan sebuah ekosistem perairan yang saat memiliki fungsi penyangga perairan di Kecamatan Bandar Sribhawono dan sekitarnya. Keempat, menambah fungsi danau Kemuning sebagai wahana rekreasi (pemancingan) bagi masyarakat.

\section{Metode}

Kegiatan restocking ini dilaksanakan pada hari Minggu tanggal 12 Juni 2016 bertempat di Danau Kemuning Desa Kali Mesin Kecamatan Bandar Sribhawono Kabupaten Lampung Timur. Bibit ikan yang digunakan adalah ikan nila (Oreochromis Niloticus) yang didapatkan dari kolam praktik Program Studi Pemanfaatan Sumberdaya Perikanan Universitas Nahdlatul Ulama (UNU) Lampung, Balai Benih Ikan Kabupaten Lampung Timur dan pembudidaya ikan di sekitar danau Kemuning. Jumlah bibit yang ditebar mencapai 11.000 ekor. Kegiatan ini dilaksanakan oleh Dosen berkerjasama dengan Badan Eksekutif Mahasiswa (BEM) UNU Lampung, Pegawai di lingkungan Balai Benih Ikan Way Curup Lampung Timur, dan Masyarakat sekitar danau Kemuning.

Tahap perencanaan dimulai dengan membuat konsep kegiatan, menganalisis kebutuhan jumlah dan jenis ikan, darimana ikan didapatkan dan, peserta dan biaya kegiatan. Tahap kedua adalah survey lokasi dan pengajuan izin kegiatan kepada pemerintah daerah setempat, yakni kepala Desa Kali Mesin dan Camat Bandar Sribhawono. Tahap ketiga adalah menyampaikan nota kerja sama kegiatan kepada Kepala Balai Benih Ikan Lampung Timur yang bertempat di Way Curup Bandar Sribhawono untuk mendapatkan bibit ikan nila yang akan ditebar. Selanjutnya menjalin kerja sama dengan para pembudidaya ikan nila di sekitar danau kemuning untuk mendapatkan bibit ikan nila sebagai tambahan.Tahap keempat adalah pelaksanaan kegiatan. Kegiatan ini diikuti oleh beberapa elemen masyarakat dan muspika kecamatan Bandar Sribhawono sebagai wujud kepedulian semua pihak terhadap kelestarian ikan nila di danau kemuning. 


\section{Hasil dan Diskusi}

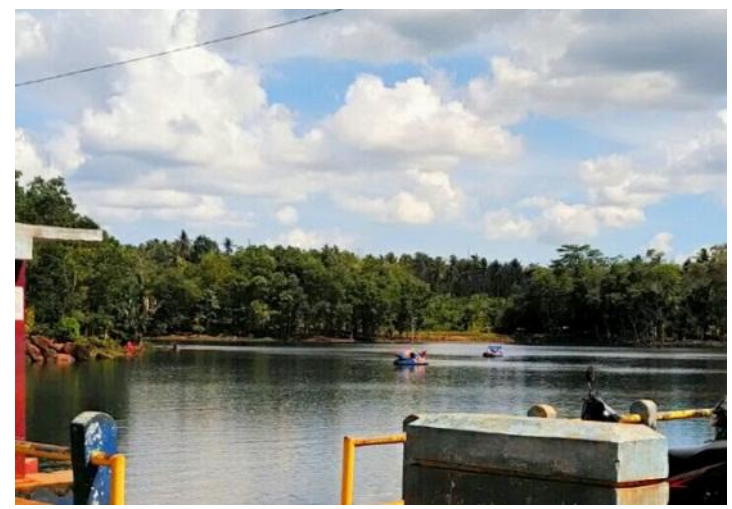

Gambar 1. Danau Kemuning Desa Sribhawono

Danau kemuning terletak di Dusun Kali Mesin Desa Sribhawono Kecamatan Bandar Sribhwono Kabupaten Lampung Timur. Berjarak kurang lebih 1KM dari pusat kota Kecamatan Bandar Sribhawono. Desa Sribawono dibuka pada hari Rabu Kliwon tanggal 3 September 1952 oleh 200 kepala Keluarga eks Pejuang kemerdekaan Lampung Tengah melalui Biro Rekontruksi Nasional (BRN). Pada tahun 1965, Desa Sribhawono diresmikan menjadi Desa definitif dibawah pemerintahan Kecamatan Labuhan Maringgai dengan diberi nama Sribhawono. Sri artinya padi atau pangan, dan Bhawono berarti jagad/hutan, sehingga dalam arti sebenarnya adalah lumbung padi atau lumbung pangan.

Salah satu destinasi wisata sekaligus sumberdaya perairan di Desa Sribhawono adalah Danau Kemuning. Pada awal nya adalah danau ini hanya dipakai untuk PDAM dan mengairi sawah warga. Namun, seiring berkembangnya destinasi wisata di Kabupaten Lampung Timur, maka danau Kemuning juga disulap menjadi wahana wisata terutama untuk yang hobi memancing. Selain itu, danau kemuning juga digunakan sebagai lokasi budidaya dan penangkapan ikan air tawar sebagai mata pencaharian warga sekitar danau Kemuning.Danau kemuning memiliki air yang sangat jernih dengan dasarnya bebatuan sehingga sesuai juga untuk area budidaya perikanan. Sebutan kali mesin disematkan untuk dusun tempat keberadaan danau kemuning dikarenakan danau tersebut juga menjadi tempat pengambilan air bersih untuk warga yang jauh dari danau dengan cara ditarik 
menggunakan mesin (Disparbud Lampung Timur, 2017)

Kegiatan restocking ini diawali dengan pembukaan secara resmi oleh Kepala desa Kali Mesin bapak Ahmad Sanusi, S.Sos. Dalam sambutanya beliau menyampaikan bahwa beliau dan seluruh komponen masyarakat Kecamatan Bandar Sribhawono sangat mendukung kegiatan yang dilaksanakan oleh Dosen dan Mahasiswa Universitas Nahdlatul Ulama Lampung.

"Kami sangat mendukung dan merespon baik kegiatan penebaran ikan nila di danau Kemuning oleh dosen dan mahasiswa kampus UNU Lampung, semoga danau ini tetap lesatari dan bermanfaat untuk warga masyarakat kami dan tentu dapat digunakan sebagai sarana praktek adik-adik dari jurusan perikanan UNU Lampung"”

Kegiatan selanjutnya adalah penyerahan bibit ikan secara simbolis di atas panggung oleh dosen Universitas Nahdlatul Ulama Lampung kepada perewakilan tokoh Masyarakat desa Sribhawono dengan disaksikan peserta yang hadir dalam kegiatan tersebut.
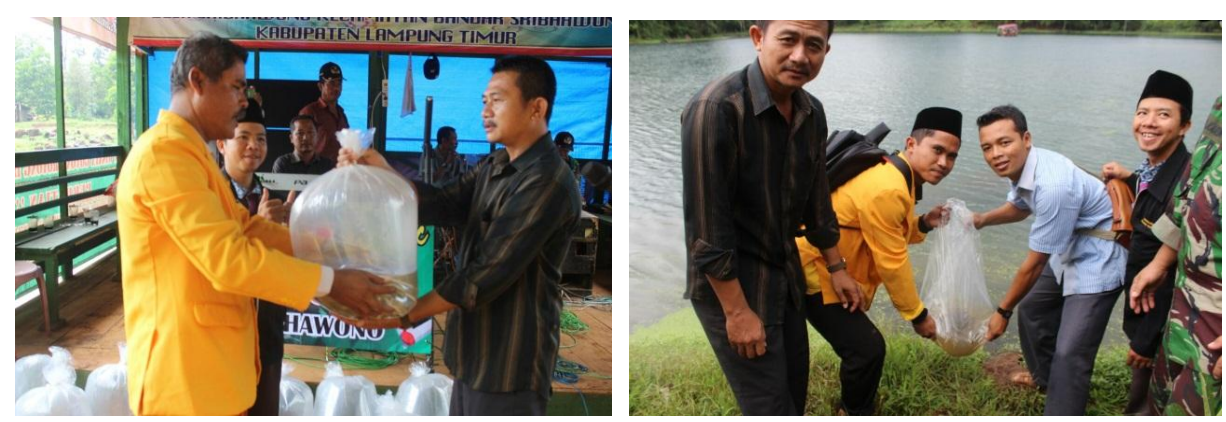

Gambar 2. Proses Restocking Ikan di Danau Kemuning Desa Sribhawono

Kegiatan selanjutnya adalah pelepasan bibit ikan nila di danau Kemuning oleh dosen, aparatur pemerintah kecamatan Bandar Sribhawono dan Desa Sribhawono diikuti oleh para peserta. Pemilihan ikan bibit nila didasarkan pada kemampuan ikan beradaptasi dan terhadap lingkungan perairan umum. Selain itu, kemampuan berkembang biak ikan nila yang cepat diharapkan mampu meningkatkan jumlah ikan nila di danau kemuning sehingga meningkatkan 
ekonomi masyarakat sekitar danau kemuning.

Menurut Amri (2003), ikan nila memiliki toleransi yang tinggi terhadap lingkungan hidupnya sehingga dapat dipelihara di dataran rendah yang berair payau hingga di dataran tinggi yang berair tawar. Habitat hidup ikan nila cukup beragam, mulai dari sungai, waduk, danau, rawa, sawah, kolam hingga tambak. Oleh sebab itu, ikan nila sesuai digunakan dalam kegiatan restocking ini. Peran serta masyarakat juga sangat antusias, dapat dilihat dari jumlah peserta kegiatan yang mencapai ratusan orang. Elemen yang terlibat diantaranya adalah dari warga desa sribhawono, polsek dan koramil bandar sribhawono serta pengelola Balai Benih Ikan Way Curup Bandar Sribawono. Setelah kegiatan usai, masyarakat berencana akan mengembangkan kegiatan restoking dan siap menjaga serta memelihara benih ikan yang ditebar

\section{Kesimpulan}

Dari uraian diatas dapat diambil kesimpulan bahwa kegiatan restocking perlu dilakukan untuk menjaga kelestarian ikan nila di perairan umum, termasuk danau kemuning Bandar Sribhawono. Kegiatan ini diikiuti oleh beberapa elemen masyarakat dan akan ditindaklanjuti dengan pemeliharaan benih ikan yang ditebar. Wujud nyata program restoking adalah semakin antusias warga sekitar danau kemuning dalam memanfaatkan danau sebagai media budidaya dan pengembangan destinasi wisata. Disarankan kepada semua komponen masyarakat untuk dapat menjaga kelestarian ikan nila,sehingga dalam tempo waktu tertentu dapat memberikan kemanfaatan bagi masyarakat terutama untuk meningkatkan kesejahteran ekonomi. 
$26 \mid$ Restocking untuk Pelestarian Ikan Nila

\section{Daftar Pustaka}

Amri, K. Khairuman, 2003. Budidaya Ikan Nila. Agromedia Pustaka. Jakarta

Burhanuddin, AI dan Nessa, MN., 2018. Pengantar Ilmu Kelautan dan Perikanan. Deepublish. Yogyakarta.

Effendi, H., 2003. Telaah Kualitas Air Bagi Pengelolaan Sumberdaya dan Lingkungan Perairan. Kanisius. Yogyakarta.

Dinas Pariwisata Kabupaten Lampung Timur. 2015. Danau Kemuning, Destinasi wisata Air. Leaflet. Lampung Timur.

DKP, Lampung Timur, 2017. Informasi Perikanan Tahun 2017. Lampung Timur.

Kordi, M.G.H.K., 2015. Pengelolaan Perikanan Indonesia. Catatan Mengenai Potensi, Permasalahan dan Prospeknya. Pustaka Baru Press. Yogyakarta.

Saputra, H., 1987. Membuat dan membudidayakan Ikan dalam Kantong Jaring Apung. CV. Simplex. Jakarta 